\title{
The Evaluation of Innovation Processes from the Perspective of Territorial Development
}

\author{
Hugo Arrillaga', Lucila Grand², Natalia Ramírez ${ }^{3}$
}

\begin{abstract}
The object of the present work is to investigate the degree of adjustment of the "evaluation studies and analysis" that are promoted when validating investment processes which involve "innovative" actions; from the contrast between the practises and the instruments applied by the main public actor of the regional innovation system with the objectives that such policies and/or programs hold as justification. In this analysis, it is verified the ability with which the evaluation practises held can generate readings of the potential impacts which are to be known in advance both, by the present evaluation models and by the unanswered questions which come out from these new technological risks and uncertainties. From this analysis performed, it arises that the promoted practises do not adjust completely neither to the traditional evaluation theoretical standards nor to the emerging demands which contemplate the new conceptualizations of risk; giving place to mistaken evaluations in relation to the contributions of such social efforts to the territorial development; an achievement which is considered the main objective of them.
\end{abstract}

Keywords: public policies; innovation; territorial development.

Centro de Estudios en Gestión del Desarrollo Territorial Sustentable y Programa de Formación en Gestión y Vinculación Tecnológica.

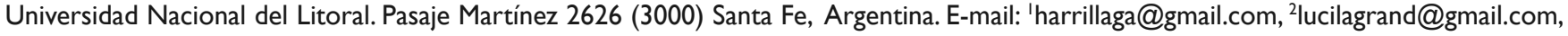
${ }^{3}$ natirabuet@gmail.com 


\section{Introduction}

The present work was presented in the XIV Latin American Congress of Technological Management ALTEC 201 I, held in the city of Lima, Perú. Besides, it is one of the results of the lines of research linked to two Projects: PICT in Red $n^{\circ}$ : 2169 , developed in the context of the ANPCYT and CAI+D in Red n: 01/09- UNL.

In the present capitalist, global and competitive model, the idea that innovations applied to the production processes of goods and/or services (which are destined to be commercialized in a market) imply social efforts which without doubt contribute to the development of the nations, it continues to have a common place. This notion has its origin in the first Schumpeterian theoretical developments, since it was this author who emphasized that the recurring periods of prosperity arising from the cyclical movement depend on innovations; and that this is precisely "the shape that the progress acquires in a capitalist society" ( Rodriguez Vargas, 2005).

The belief that "innovation is a cause of development" is generated by Joseph Schumpeter (Montoya Suárez, 2004). A belief which has been sustained until now, because the degree of innovation in an economy has a direct incidence in the degree of competitiveness of its productive organizations; which means higher levels of efficiency in the use of resources, thus contributing inexorably to the expansion of the National Product which has a positive impact on the economic system and, in general, on development. In order to point out only other more recent opinions, which in this sense have had a high incidence in the contemporary knowledge in the field of technological management, it is worth mentioning Michael Porter, author of "The competitive advantage of Nations" (1990) when he states: "A nation's competitiveness depends on the capacity of its industry to innovate and improve itself; the enterprises get advantages if they manage to innovate ..."

The association of the concepts of " innovation", "growth" and "development", has led to the creation of an image in which such stages are the different and following phases of only one process, before which the promotion of innovations implies implicitly the contribution with the development of a social system, to the extent that such conceptual triad, was recognized as the function of the World Intellectual Property Organization (OMPI) by its General Manager, in the Assembly of the State Members in September 2010. Hence, this type of assertions sustained during the 20th Century, became the assumptions and convictions from which they started in the formulation of public policies. This direct association, implied in the abovementioned triad, has led several times to the situation in which the promoted public practices, conceived at least formally from these certainties, have effects on the socio-territorial structures beyond the effects originally envisaged and expected. Impacts of a negative sign in most cases and, most of the times, with multiple effects of diverse signs and even of a contradictory nature.

As regard this last notion, there were several authors which alerted about these possible consequences; among them, it is worth highlighting Solow (1956), who was one of the first to point out that the increase in social inequality is a lateral effect of the economic growth and he also stands out the need to identify policies which tend to mitigate those "unwanted effects". He also recovers Marshall's ideas (1980) on external effects and Pigou's developments (1920) when he mentions the differences between the private net product value, produced by the social product, attributed to the market failures and identified them as "externality". These developments are taken in the future by Baumol (1972), who adjusts them to the economic contemporary conceptions in its work "On Taxation and the Control of Externalities" half a century later.

Regardless the deep reasons why externalities occur [being basically understood as differences between the private costs and benefits and the social costs and benefits], whether for the causes stated about the absence of a market that guarantees the internalization of the costs or because the consequence of the model of accumulation dominant in a certain socio-historical production model (an analysis which goes further from the specific object of this work); what is objective and verifiable is that such differences occur in any type of investment project (innovative or not) and that they normally have asymmetrical and socio-territorial impacts.

In Argentina's own experience in the last decades, we can find clear examples of these situations, which is the case of the transformations which materialized in the farming sector in the last two decades. In this sense, it is well known and it has already been described by a high number of authors, the expansion which was verified in this productive activity, which lead to an increase of a $50 \%$ in the surface used only in the Pampean Region while the volume of production achieved increased in the same term more than a $120 \%$.

This increase in its productivity was based on a set of innovations which were incorporated to the production model, both in the production techniques (new farming methods), as in the management techniques ( professional and TIC's), in the applied inputs (seeds genetically modified, new generation of agrochemicals), in the capital goods (chisel plough, precision farming), among other aspects all of which merged, with no doubt, in one of the cases of higher growth in competitiveness of an economic sector [the analysis of these innovative transformations were exhaustively described in several works, within which it is worth mentioning: Giberti(1993, 1994, 200 I, 2003), Craviotti (2000), Bisang (2003), 
Díaz Rönner (2005), Manuel Navarrete et al (2005), Giarraca and Teubal (2005), Barsky and Dávila (2008), Arrillaga and Grosso (20I0)].

The result of this group of innovations applied to one production process was shown in a whole series of effects of different signs, which reached the whole population in different forms. Within the positive sign effects, we stand out the significant contribution which included the wealth generated in the territory (GDP= Gross Domestic Product) which went hand in hand with a positive re-composition of the entrepreneurial benefits of the whole related productive activities, of the farming income, of the balance of payments and of the Tax Revenue.

But, as a counterpart, it has been registered a strong process of concentration of capital and in the work of the land in particular, which led to a significant decrease in the number of farming producers and also in the people who lived in the farming areas, due to a strong withdrawal in the volume of demand of rural handwork together with a change in the qualifications required in the new demand of human resources.

These facts caused important movements of the scattered rural population towards the overcrowded forms of residence, with a specific orientation towards the micro and small areas, which generated a strong variation in their labour markets, with a clear expansion of the precarious working conditions and in the inequity levels in the distribution of income, among other aspects [standing out in the present Project of Research: Arrillaga, Grand, Locher, Busso, 2007; Arrillaga y Delfino, 2009; Grosso et al. 2009; Domínguez y Orsini, 2009; Grand y Ramirez, 20 I0;Arrillaga, Delfino y Trucco, 2010]. Other impacts, whose scale, range and slant are uncertain, are added to this group. This a fact which has been promoted mainly from the contradictory character of the public opinions stated.

We stand out that there coexist recurring complaints for adverse environmental impacts promoted from a vast group of social organizations, with the systematic rejection and invalidation of them, being produced by other types of social actors closer and linked to the decisions which motorised these transformations in the farming productive activity.

This controversial situation took place at the academic level, with the appearance of divergent opinions as regards toxicity, for example. Nevertheless, the Scientific Commissions of the National Executive Power and those of the Justice assigned to analyse the particular case of agrochemicals and its eventual effect on human health, agree on the low level of information available to arise to a conclusion of fundamental nature [here we make reference both to the report performed by the National Commission on Agrochemical Investigation and the CONICET "A Scientific Information Assessment in relation to the Glyphosate and its incidence on human health and the environment." (July, 2009), as the report generated by the "Universidad Nacional del Litoral" entitled:"Report on the Glyphosate Toxicity."(Sept, 20I0)].

The situation of an emerging social tension contributed to lead the population towards a clear situation of uncertainty, a situation which in itself implies degradation in their life conditions. All these ended in manifestations of social conflicts, reflected in several public demonstrations, giving birth to a number of legal claims. Nevertheless, we stand out the asymmetrical set of welfare and discomfort situations caused by this current of innovations does not have an end in the ones described, the group is significantly more complex and wider, but its detailed research is a task which exceeds the objective of this work.

The specific object of this work is, in turn, the research of the level of adjustment of the "evaluation studies and analysis" which are carried out in the public space of the Regional Innovation System (RIS) of the Province of Santa Fe, when analysing the reason and convenience of promoting, financing and even subsidizing $C$ and $T$ processes and/or technological innovations. This implies the recognition and appreciation from the "public interest", i.e. from the interest of the whole society (present and future), of how the recommended and ruled practices for the stages of "evaluation" of the promoted policies of encouragement to innovation, give an answer and adjust to the progress achieved in the academic field in the last decades in three thematic fields: development, risk and evaluation analysis theories.

The hypothesis put forward can be summarized as:"the evaluation practices promoted by the State about the encouragement and/or promotion processes of the scientific and technological activities and of the innovation in the SIR environment, are mainly limited to guarantee the feasibility from the point of view and interests of the person responsible of the initiative", a fact which if verified would not guarantee the social convenience of this effort, since giving this type of answers necessarily implies an amount of information and more complex evaluation stages than the ones usually performed. Such a situation would create a scenario in which society, through its state structures and organizations, would be facilitating the implementation of initiatives which could be opposite or unfavourable to their own interests.

Nevertheless, it is worth mentioning that this is a case in which the hypothesis can admit different answers, since the theoretical concepts used (innovation, development, evaluation and risk) are polysemic because they are socio-historical constructions; the reason why the theoretical perspectives of this analysis are defined in the following item. 


\section{Innovation, development and assessment; The refer- ential concept of development}

It is of relevance to mention the referential concept of "development" adopted, since we would like to explain the meaning and scope that is given in the present work. In no way we want to fix noun criteria and/or definite criteria in the subject, but simply explain the approach chosen in order to avoid the possible misunderstandings which are normally derived from the diversity of interpretation historically built. [The "referential concept" of development accounts for the possible theoretical conceptualizations built in time by the different currents of knowledge, in this case applied to the notion of development. The "referential concept" is based in the polysemic character of the term. In this sense, the idea of the "referential concept" mobilizes the ideologies of the wished and recognized as positive and necessary, without studying thoroughly the analysis of the strategies for its achievement].

Its first connotation is circumscribed to an economic system characterized by the volume of wealth generated. Thus, the achievement of positive impacts in the growth rates of an economy resulted to be the "adequate path for development". Schumpeter (1978), father of the concept and of the relevance of innovation in itself, pointed out in the 30's that: " both the material factors (work, land and capital) and the immaterial forces (the technical facts and social organization results), condition nature and the level of development".

However, practically since the coinage of this concept, there have been advances in the construction of more complex meanings, which started to widen and make its purposes more complex without leaving aside the expansion will and the capacity of generation of wealth (in terms of the social values incorporated). Thus, this concept moved forward progressively incorporating other dimensions, such as the distributive equity, the rights and interests of the minorities, the environmental sustainability, human rights and, in particular, of the future generations in a "clean" environment which assures the possibility of meeting its needs.

The main controversies in the "referential unit" adopted, arise from the survival of attitudes which are only mobilizing, explicit and implicitly, an economic dimension of itself; although, in many cases, without rejecting other scopes but ignoring them in the surface of operationalization of the policies.

On the other hand, a clear correspondence between the process that structured the increasing complexity of the concept of development in the last half a century, and the evolution that at the same time had the "human rights", characterized by Thomas Marshall [published in his work:
"Citizenship and the Social Classes", in 1950, by the University of Cambridge] in his famous triad and coined later on by Karel Vašák under this name. [Karel Vašák was the first General Secretary of the International Institute on the Human Rights and introduced the concept of the three generations of human rights in the Conference held in 1979, in the premises of such an Institute in Strasburg]. It is precisely the maturation process of the third generation rights, also known as the "rights of the people" or the "rights of solidarity", which are assessed in the 70's and 80's doctrine, which strongly influence in a redefinition of the concept of development.

The progresses strengthened in the theoretical field, do not go far beyond the debate between experts. In 1987, the World Commission on Environment and Development of the United Nations, led by Dr. Gro Harlen Brundtland gives birth to the document known as "Our Common Future".

This is the first time that in a document of multilateral characteristic, the concept of "sustainable development" is incorporated and it is defined as: development that meets the needs of the present generations without compromising the ability of future generations to meet their own needs." Its importance is fundamental, since it is from the UNO, that it is proposed that the process of development must compulsorily contain and give an answer to the three big dimensions of analysis: the economic, the social and the environmental. This report, is later known as the "Brundtland Report"

On the verge of the new millennium, the human being experiences other worries and, in relation to them, new ideas start to be worked on the rights that should protect them; being identified as the fourth generation of human rights (Bustamante, 200I). They refer to the protection of men against new technologies, since the technological innovations are the ones that constitute one of the shaping factors of the present situation, carrying on several impacts on the human being, both at a level of material context and in the structures of interpersonal relation and in the modelling of identity and conscience.According to the same author, these structures "have played in favour of the constituted powers." In this sense, in the years to come we will assist with no doubt to a higher level of recognition and dedication to human rights against a universe of emerging technologies, as well as to the referential concepts of development which would account for in a more precise way than the one put forward by Max Neef (1993) on the ways in which the articulation between human needs, nature and technology should be solved. [There follows a non-exhaustive list of the third generation rights and, similarly, one of the main "referential" of development which arise from that time:Third generation rights or "Rights of the people" or "Solidarity rights": they are identified as the ones which refer to the right of people's 
self-determination; economic independence and politics; national and cultural identity, peace, peaceful coexistence; understanding and trust; regional and international cooperation; international justice; use of scientific and technological progresses; to a clean environment; common heritage conservation; the rights of all kind of minorities: religious, ethnic, sexual, political, etc.) The School of Development on Human Scale (M. Max Neef, et al; 1993;90) points out that the Development on Human Scale concentrates and is based on: the meeting of the fundamental human needs; the generation of growing levels of self-dependence; in the organic articulation of the human beings with nature and technology; in the articulation of the global processes with the regional behaviours; in the articulation of the personal side with the social side; in the articulation of the planning of autonomy and in the articulation of the civil society with the State].

\section{The concept of innovation}

In the concept of "innovation" significant differences can be observed in the term, which have become more notorious in the last time. In the mid 30's, Schumpeter as the father of this concept, comprises innovations from a set of possible cases: the introduction in the market of a new good, the introduction of a new production method or of marketing of new products, the opening of new foreign markets, the creation or implementation of new market structures, and/ or the change in the sources of supply for raw materials or inputs. He sees innovations as "historic and irreversible changes in the way of doing things" (Rodríguez Vargas, 2005) Escorsa and Valls (2003) have compiled different conceptualizations in relation to the meaning and scope of technological innovation, pointing out a wide coincidence between the authors cited and Schumpter's initial formulations. The transversal idea refers to the incorporation of important changes in enterprises, whether in the products they manufacture, in the ways of producing them and in the form of introducing them to the markets. Innovation is, from this point of view, a significant transformation materialized and validated in the market.

In the same line of thought, the Oslo Handbook (OECD, 2005) defines innovation as the introduction of a new product, good or service (or the same product significantly improved); a new process, marketing method, organization method in the internal practices of an enterprise, of the place of work and of the relations to the foreign markets.

In this current of thought - in which an endless number of authors are comprised- the commercial object of the changes introduced in the production processes and the profitability as an end of the promoted activity, emerge as the distinctive characteristics of the process in order to be recognized as innovation. The definitions generated in this sense do not host cracks or interpretations.
The innovation field was not only approached from the described perspective, there exist other currents of thought which understand that the field of innovations does not only end in the ones that the market reaches, but in any type of innovation (onerous or not) whenever it is used or applied to meet social needs.

Therefore, from other lines, innovation is defined as any change, of permanent consequences, in the organization and/or production way faced by a social group. They do not leave aside the efforts focused in giving their productive structures a higher degree of competitiveness, but not only limiting to it. They encourage novel forms of innovations in every environment; assuring that competitiveness constitutes the axis of a territorial development model, wishing for the construction of an innovative society in every aspect of work, where citizens are able to live the values associated to innovations and adopt new behaviours and attitudes. [Taken from Innobasque (Basque innovation Agency), which is intended to transform Euskadi into a European referent as regards innovation (http://lasindias.net/indianopedia/ Innovaci\%C3\%B3n)].

In most countries, not only the marginal ones but also the central ones, a high number of initiatives which try to encourage innovations conceived from this scope wider than the traditional one; convinced of the high interaction existing between the resolution of the main society problems and challenges with the competitiveness of its productive structures. Howaldt and Schwarzs (2010) indicate that technological innovations are deliberated innovations, designed to start and affect in the future evolution of society, whether in technology, in economy or in the social practices. These wider interpretations ended, in many cases, identified with adjectival functions to the effects of distinguishing them from the more restricted sense they originally had. It is common to find names such as: social, cultural and health innovations and even in aspects not so different from the initial ones: business development, financial services, among others [Administrative Department of Tecchnology and Innovation of the Republic of Colombia].

Mulgan's Proposal (2007:9) as regards the concept of "social innovation" refers to "development and implementation of new ideas, products or services to meet social needs". Therefore, we support the idea of the need to open the original theoretical perspective in relation to the concept of "innovation," but it does not solve the delimitation between the types of innovation (social and technological).

This same author notes as potential distinctive criteria the type of needs: social or personal. In other cases, the intangible and immaterial character of the first type is pointed out. Howaldt et. al. (ob.cit) suggests the application environ-

ISSN: 07 I8-2724. (http://www.jotmi.org)

Journal of Technology Management \& Innovation (c) Universidad Alberto Hurtado, Facultad de Economía y Negocios. 
ment, since social innovations do not occur in the middle of a technical device, but at the level of the social practices. The Hunger Sudies Institute, Spain understand them as products, techniques, methodological procedures or processes developed at a community level to solve problems related to food insecurity, vulnerability or social exclusion. [http://ieham.org/ $\mathrm{html} /$ tecnologias.asp]. Together with more than the ones mentioned, the Bank of Brazil Foundation argues that they include products, reapplied techniques or methodologies developed in the interaction with the community and that they represent efficient solutions of social transformation [http:// www.adital.com.br/Site/noticia.asp?lang=ES\&cod=3887 I].

There exist other interpretations such as the one from the Research Center on Social Innovations (CRISES, 2007), in which social innovation practically encloses technology. It argues that "social innovation represents new practices or focuses, introduced with the object of: improving the social and economic profitability of the public or private organizations, in order to solve a relevant problem for the social actors, cover a deficit in the existing norms or even in the social and community coordination to meet new hopes and needs" (Calderón Vázquez, 2008)

In this context, the meaning given to the concept of "innovation" in the present work refers to its wider sense, in the same way as the CRISES suggests, i.e. that the ability to affect positively at a level of development of a socio-territorial system is recognized; supporting the more modern and complex referential units of this concept.

\section{The evaluation analysis of the projects/innovatives}

Also known as evaluative investigations, they constitute, from many years ago, a body of knowledge with a theoretical field of its own, different from the social sciences, engineering and even behavioural psychology; even though it takes something from most of them and that implies a clear interdisciplinary configuration.

Although its development, recognizes precursors as Blaise Pascal (17th Century), it comes from the hand of Jules Dupuit (1844), who makes progress both in the recognition of the need and also in the theoretical developments, which allow the facing of the problem of decision analysis in investment projects. In 1902, the analysis acquires the form of a legal standard, since the approval of the "Rivers and Ports" Law in the USA; followed by the "Flood Control Law" in 1936.

The differences between both legal norms imply, in the first case, the obligation to secure the reasonableness of the investment, contrasting the commercial costs and benefits expected of its exploitation. While the second Law widens the object established, suggesting the need of a reading of the effects made by an investment postulating the obligation of contrasting "the calculated or expected costs with the profits earned by whomsoever".

In this way, since the historical interaction produced between the theorists from several disciplines, mainly in economy from the end of the 19th c., and the wills and political decisions taken in order to guarantee higher levels of rationality in the public and private administration, a kind of dynamic pressure was generated in this complex interdisciplinary theoretical field, which led it towards a rapid evolution during the 20thcentury. Mainly from the beginning of 1950, its first formal and methodological expressions were achieved, as it was the case of Green Book (Arrillaga, 1997). Hence, even though the original object of the evaluation analysis has not substantially changed in time which, following Cohen and Franco (1988), can be summarized as: “... evaluating is fixing the value of a thing and to do it we require a procedure by which we compare what it needs to be evaluated in relation to a certain pattern or criteria...; there have been significant progress in the complexity given to it, recognizing both different evaluation "viewpoints" and "patterns". In the first case, the different viewpoints account for the different types of actors from which the convenience of an investment initiative can be judged. While in the second case, the different "methods", face different "criteria" or "patterns" to be applied to the estimation process of the value of such initiatives.

In general, although in the specific literature we do not observe important criteria in the recognition of the possible analytical points of view, there has been progress in the identification of three possible options: the "financial, private or commercial" [it is recognized with these different names in the thematic literature even though the existence of contradictory meanings is admitted] evaluation, the "economic" evaluation and finally the "social" evaluation.

The "financial" evaluation implies the judgement of reasonableness of an investment process from an analysis and contrast of the resources used and it generates the project for a certain actor; normally for the responsible of such investment. Therefore, the range of the evaluated effects is limited to the consideration of the "direct" ones (Solanet, 1984). In the case of "economic" evaluation, the analysis performed pretends to account for the results that the whole society expects from a project, considering it as an aggregate in which the internal transfers (whether of costs or of benefits) do not vary the expected result.

Finally, it is highlighted the "social" evaluation, which is similar to the economic one, in the sense that it pretends to 
read the effect on society as a whole, but, in this case, corrected by the redistribution process of wealth that cause, whether in social, territorial or generational terms (Mokate K.M., 1987; Infante V., 1988; Sepúlveda, 2000).

In the case of methodologies of analysis, they also agglutinate in three big types: the "cost-benefit analysis" (CBA), the "cost-effectiveness analysis" (CEA) and the "multi-criteria evaluation analysis" (MEA). These options are mainly differentiated in the measure applied in the measuring process of impacts (positive and negative) in the words of Cohen and Franco (ob.Cit).

In the same way as in the "CBA", the contrast is performed in relation to scales done in an only and common denominator (the currency unit), The "CEA" does it through the application of two measuring units (two attributes), in which are expressed separately the expected costs and benefits, while the "MEA" uses multiple attributes, facilitating the construction of judgements made from a sensibly higher axiological complexity, without the risk of re-expressing the effects of an attribute that is not its own.

It is worth mentioning that about the last observation there is not important agreement within the academic field, since in many cases what is highlighted as a virtue, is a strong limitation. Such is the case of Sepúlveda (2000: 4) when he argues:

"There are many elements of social welfare that are difficult to quantify, and, in some cases, it is practically impossible. This is the problem of the social evaluation: to determine the value that the positive and negative effects originated by an action or by a specific resource allocation have for society..."

The criticism of higher scale about the evaluation methods of Cost/Effectiveness and Multi-criteria, is given in the absence of formally objective answers as the ones guaranteed by the CBA from any analytical viewpoint that promotes it. In these cases, it is worth emphasizing the absence of certainties in relation to the degree of "efficiency" of the evaluated action which remains available to any type of political consideration.

Nevertheless, and in defence of the profitability and the ability of the alternative methods to the CBA, it is suggested that a social value to be recognized as such, does not necessarily require an equivalent currency value (price). The rational social action does not always have to be adjusted to a Cost/benefit ratio. There are other logics that can also explain human behaviour, within which we can highlight the reasonableness as regards human values (Weber, 1996). This argument gets stronger as long as the procedures to de- termine the equivalent monetary values are strongly questioned, because the available techniques show in their readings the inequity (social, territorial or generational) which in relation to income distribution is manifested in the territory under analysis.

Almost in every method of evaluation which are aimed at estimating the monetary value equivalent to the goods and/or services not commercialized in a market (necessary condition for its inclusion and "CBA" treatment) [we make reference in this case to the methods: "updated value of the possible future income," "hedonist prices," "quota assessment," "trip or illness costs," etc.], the result is codetermined by a set of explicative variables, within which the actors' income is underlined. In such a case, the bias added to the estimated value by the variable "income," can only be corrected from a determination taken out of the territory, i.e., generated from a global scale. In view of that, the formulated criticism from positive discount rates in the updating procedures of the monetary flows (Martinez Allier, 1998). In this case, the reason held is that it implies the introduction of biases in the intergeneration preferences; which results contrary to the concept of sustainability when representing the temporal preferences of today generation in such discount rate.

It is worth highlighting that in the course of time and, mainly, in the last decades of the last century, at the same time that new social values were substantially recognized and incorporated to the referential of development socially maintained, complementary analytical bodies started to be generated trying to cover the reading of the effects related to new worries. Such was the case of the Evaluation of Environmental Impacts and of several analysis of viability (legal, technical, institutional, financial, social, etc.).

The theoretical-methodological production that with such objects was performed, was progressively recognized through several public policies [such as the case of the Public Investment System of the Argentine Republic (Law $\left.\left.N^{\circ} 24.354\right)\right]$ and of institutional and academic practices, such as the main multilateral organizations of investment financing (IBRD; IDB; CFI; etc.).

In spite of these developments, the evaluation analysis still has empty spaces, and is not able to give an answer to new questions, knowledge and social and academic worries. For example in the case of not being able to face the risk consideration and treatment and uncertainty situations generated by its own evaluated projects.

Moreover, it is worth pointing out that every project implies risks in its environment [if they are not known in terms of occurrence probability and/or in terms of the scale of the impact or effect which brings, they are recognized as 
uncertainty situations. The concept of "risk situation", from this analytical point of view, remains preserved exclusively for those situations in which the potential damage and its probability of occurrence are recognized]. Nevertheless, the standard procedures of evaluation (Baca Urbina, 1992; Infante Villarreal, Ob. Cit; Sapag, 1998, among others), forecast within the proposed analysis, the express consideration of the performance in eventual conditions of "risk and/or uncertainty". But the risk under these points of view, is given in the possibility of having an answer of "benefits" or of "profitability," different from the estimated in non-contingent situations; where the purpose is to generate an estimation of the possible dispersion that the answer of a project and the possible probabilities of occurrence can have.

The increasing importance that the risk social conscience has had along the history, expressed in the fights and efforts made by its dominance and control, is clearly observed in the traces left by the explanations and theoretical productions made in order to determine both its origin and its management forms (alert, precision, prevention, anticipation and mitigation, etc.). This is a distinctive phenomenon of contemporary societies, since the new risks faced come with the intervention of decisions taken by the same social actors (Beriain, 2007).

In this case, the description of the historical evolution of the risk concept is omitted, pointing out that until the Middle Ages its explanation was characterized by a strong mystic character while modernity gives way to the rational thought which arrives to the conviction that "destiny" is not only natural, but a socio-historical construct; mainly as a consequence of an unfinished risk dissemination (Beriain, ob.cit). The study about risk as an object of investigation in itself, has registered progresses from the different disciplinary looks both from the natural sciences and from the social and applied sciences. They have done that in the last fifty years without being able to arrive to a consensus on its conceptualization, what in a way hampers the creation of a "substantive theory" which allows the articulation of the different promoted research results in a common work field (Bechmann 1995 in López Cerezo and Luján López, 2000; Cardona, 200I; Arrillaga et al, 20I0).

As regards this analysis, several approaches have been structured, following López Cerezo and Luján López (2000), such as the "technical approach," of a clear positivist tradition, which gives the risk an objective, quantifiable and, consequently, an "acceptable" character from the determination of its "expected" value, in clear harmony with the evaluation method "CBA". The second analytical paradigm, is known as the "psychological approach," which reveals the subjective character of risk, in relation to the idea of "perception". Its development is not antagonistic with the preceding one. In the third place, there appears the "sociological approach," which if appears as opposed to the "technical," it moves forward on the "psychological approach" but from a collective perception. From this point of view, the risks are comprised as "social constructions" that depend on political, economic, social and cultural factors, which are linked to the existing social structures. Here, the risk acquires a public and political character (Beck, 2000) which gives place to the social conflict and to demonstrations of social groups affected by technological disasters. This approach incorporates the perspective of "cultural anthropology" (Douglas, 1996), for which the risk acceptability will depend on the social context or on the cultural characteristics of the societies in which it appears.

In the fourth place, it is worth highlighting the emerging contributions from the so-called Latin American School, mainly oriented to "Risk Management" (Hewitt , K, 1963; Mansilla, E., 1996); Cardona, O., 200I/3; Lavell, A., 2004; y $\mathrm{H}$. Herzer, et. Al, 2004) which recovers the contributions of the objective and subjective theories, but it stands out "the disasters are seen as consequences of the conditions in every-day life, not as a phenomena on the edge of it" C. Pérez de Armiño (1999). Its main contribution is given in the recognition it makes of the elements which make up a risk configuration; distinguishing in this case two contributory factors as follows:

- The threats to which a territory is exposed, understanding them as the elements or triggering events [here, although the literature has recognized in time two types of triggering events: those of natural origin and those of anthropic or technological origin, in a more modern analysis it adds and recognizes them as a socio-natural phenomena, since in spite of the fact that those which manifest through the natural system for having lost itself their pristine condition for being this system progressively more anthropic, the accumulated human behaviours and practices, influence more and more in the way of manifestation of the natural system].

- The level of vulnerability of such a territory or social group against each of these threats in particular. This comes from the idea that for a disaster to occur, the territory in which it is manifested, must be vulnerable to a threat, i.e., it should be characterized not only by its peculiar degree of exposure to it, but also needs to have a low degree of resilience (Cardona 200 I;Arrillaga et al; 20I0).

A multiplicity of explanation factors are found in the root of vulnerability, among which we can mention: "physical, economic, social, political, technical, ideological, educational, institutional, organizational, cultural, environmental and ecological," (Sanchez del Valle, 200I). In this same line, Cardona 
(200I), suggested that "vulnerability is the degree in which the different social classes are put differentially at risk."

The problematic which risk offers in this context, is focused in the incompetence on the side of social groups or individuals to find the mechanisms or means to feel protected from threats. In Castel's words (2004), the insecurity of contemporary societies still has on its shoulders both the weakening of the classic protections and the new threats coming from the technical and scientific field. From these theoretical constructions, Giddens (2005) points out that this new age and its cracks, is based on unintentional and unexpected consequences by individual and collective subjects, characterizing itself as an age of "manufactured uncertainties" by the same human action.

Beck (1999) identifies it as the "risk society," since it can affect the environment, ecology, human health, food security, among others. Thus, the uncertainty and insecurity are the stage on which these "new risks" perform, and they are considered the product of the scientific and technological development.

As regards this new form of characterization, neither the traditional evaluation nor its addendums in terms of EIA's, cover the worries that have been reflected.

\section{The evaluation of innovation encouragement processes}

This item intends to present the results of a preliminary examination in relation to the range of the project evaluation procedures that, with the aim of generating innovative processes, are encouraged from the public action in the environment of the Innovation System of the Province of Santa Fe. For such an objective, and as an exploratory stage, the instruments (Programs and Projects) were selected and analysed. They were supplied by the National Agency of Scientific and Technical Promotion (ANPCYT) [The "ANPCYT" is an Organism dependent from the Ministry of Technological Science and Productive Innovation of the Argentine Republic, with the direct responsibility of promoting the activities related to science, technology and productive innovation, which was created in the year 1996]. This Agency has as institutional object:"to contribute to improve the social, economic and cultural conditions in Argentina" [http:// www.agencia.gov.ar] and fulfils such an object by promoting and financing a wide variety of projects, which are intended to scientists dedicated to basic investigation, and to enterprises interested in improving their competitiveness from the technological innovation.

Its financial source is the National State, which has both own resources as external financing source, such as the IDB
(Inter-American Development Bank) and the IBRD (International Bank for Reconstruction and Development). The Agency has structured its operative function in three big areas, from which the projects defined as credits or subsidies are financed. [The dimension of its contribution is not only significant but the biggest effort promoted with this aim in Argentina. In the 2008-9, the Agency financed more than 4000 projects for an amount close to the 200 million US dollars. In such period, the $58 \%$ of the resources were moved through the FONC and T, following in place the FONTAR with a $39 \%$ and sensibly more delayed the FONSOFT and the FONARSEC with a $2 \%$ and I \% respectively (Management Report of the ANPCYT: 20008-9)]:

I. FONCyT (The National Fund for Science and Technology Research: has as an aim to support projects and activities whose aim is the generation of new scientific and technological knowledge -both in basic and applied subjects- developed by researchers from non-profit public and private institutions based in the country. The main types of projects promoted are destined to generate new starts in all the $S$ and $T$ (Scientific and Technological) areas. The results are destined first to the public domain and are not subject to conditions of commercial confidentiality (PICT), or of interest for a counterpart ready to co-finance it (PICTO).

Another line is destined to the acquisition of pre-competitive results or of a high social impact. They are presented with one or more adopters -enterprises or institutionsready to co-finance them, who have the priority of acquisition of results (PID). Others are destined to the updating of equipment (UEP), strategic areas (SAP), scientific Meetings (SMP), strengthening of Human Resources and Infrastructure in $\mathrm{C}$ and $\mathrm{T}$ Institutions (HRP) and (PROMIN)

2. ATNF: Argentina's Technological National Fund: it administers both public and private resources and finances innovation projects, among which can be remarked those who have as a goal to improve productive structures and the innovative capacity of enterprises which produce goods and services in different types of activity.

3. FONSFOT: Trustee Fund of the Software Production Industry: it promotes the strengthening of software production activities at a national level. It finances:

a. $\quad \mathrm{PI}+\mathrm{D}$ related to the activities included in the pro motion regime (creation, design, development, production and implementation and revision of software systems).

b. Training Programs on human resources,

c. Programs for the improvement of the quality of software cration the process, design, development and production. 
4. FONARSEC:Argentinian Sectorial Fund: has an aim to improve the competitiveness of its own sector, contributing to the solution of diagnosed problems, giving answers to the demands of society, the enterprises and of the State.

In order to cover the worries for the impacts of its action, the Agency creates within its environment, a Socio-Environmental Management Unit, with the function of identifying and examining the socio-environmental consequences of the projects presented through FONTAR AND FONCy T. Especially, and during the execution stage of the projects, it gives priority to the follow up of "those of a high environmental sensibility, making recommendations and assessment in relation to the environmental certificates and authorisations according to the trading names; the management of solid waste; the management of effluents; generation and control of gas emissions, noises and vibrations; the use of chemicals, usage of water and intensive usage."

Given the IBRD'S intervention in the financing structure, the binding loan agreement incorporates two Attachments: the $\mathrm{XI}$ is the Operating Manual of a Socio-environmental Management Plan, which sets the obligatory nature of fulfilling social and environmental hardships and adjusting the procedures, in any particular case, to the CONABIA Norms, OMS, European Community, from the Guide on Good Practices of the SA and DS, and the Hygiene and Security Norms from the SRT (Law N ${ }^{\circ}$ 1958/72). In view of that, the XII Attachment sets a guide for the mitigation of environmental impacts in smaller constructions.

\section{Conclusions and Recommendations}

[It is made clear that some proposal practices which are detailed hereinafter, were incorporated during the year 2012, after the presentation of this work in ALTEC 20II, Lima-Perú]

To the effect of proceeding to the proposed analysis, a contrast between the institutional aims and objectives of the Agency (ANPC and T) was made with practices of the evaluation processes, which arise from the operating and instrumental guidelines in the promoted innovation projects. Such analysis arrived to the following results:

I. The ANPC y T supports in terms of its mission and of its institutional objectives a complex referential of "development", which goes far from the economic and includes the social, the cultural and the environmental points. Similarly, the concept of innovation on which it organizes its activity, goes far from the technological point of view, addressing innovations of a social character.
2. In the programs and projects designed by the Agency - although they are generally coherent with their political objectives and they suggest investment options where the beneficiaries can be both enterprises (beneficiary) and other institutions of social interest - it is observed a particular direction from each of the financing areas in which it is structured.

3. In this sense, while the FONTAR is guiding private enterprises- therefore the promoted innovation is limited to those enterprises which end in goods or services towards the market-, the FONC y T has a direction oriented to the production of new knowledge, which can be formalized with pre-agreements and co-financing- with public or private organizations.

4. Most of the promotion instruments authorised in the frame of the FONCYT does not suggest financial, economic, social, environmental evaluations or those about territorial risks. The formal duties are formulated in relation to the ethical, environmental and security safeguard (as a sworn statement); with the exception of I + D Projects, which require an estimation of benefits expected by the adopter and non-exhaustive information about externalities. [This includes: market analysis, production of answer indicators (VAN, TIR) possible benefits oriented to clients, consumers or social sectors, financial analysis (although it is a financial viability analysis because it includes the ability of fulfilling commitments) experience and effect of the project results in the enterprise, province or social sector].

5. In the case of FONTAR Projects, it is normally required an estimation of the incremental costs for the enterprise, information about the impacts on the permanent and direct employment and in the external sector (although not necessarily quantitative). Besides, it is needed an environmental sworn statement, with a commitment to compliance with the sectorial regulations in force and, in case possible socio-environmental impacts are estimated, the expected mitigation measures is also needed. Apart from the abovementioned, an economic, social and environmental justification is asked for, even though in the economic memory it is suggested to estimate the impact on the enterprise -financial evaluation- comparing the situation with or without a project.

6. In the case of the operation CAE-BICE (Credits to enterprises- $\mathrm{BICE}$ ), a risk analysis is requested, and although it is detailed that it is about the technical risk, its scope is not described, i.e. if it is about the project or about the context or if it operates on the threats or affects the territory vulnerability. 
7. In the Operating Regulations (BID operation) the concepts of "feasibility" and "evaluation", are used as synonyms, without distinguishing the difference in the scope.

As a general conclusion about the evaluation processes, it is suggested that in its instrumental aspect, they are predominantly directed towards the procurement of an estimation of the answer expected from these innovations by the beneficiaries of the encouragement policies.

The analyses required in terms of economic, social and/or environmental impacts, are mostly of a descriptive character, without emphasizing neither the need to demonstrate its justification from society's point of view as a whole (economic) nor the particular impact on the sectors and/or territories of a higher vulnerability (social); while from the environmental point of view, it is not requested explicitly the EIA, limiting to a Sworn Statement to be fulfilled in the future.

As regards the potentially emerging territorial risks and their possible manifestation as an expansion of social vulnerability, its evaluation is not covered, although it is admitted that this type of evaluative analysis has not reached an important theoretical development yet.

To summarize, it is then emphasized that the underlying logics of the reasonableness of encouragement to innovation practices is the one that understands as beneficial in social terms what is beneficial in private terms, which raises doubt about the real and effective contribution to territorial development.

Therefore, it is recommended an exhaustive revision both of the evaluation processes for each stage of development in an innovative process, and the documentation and justification required in order to have access to encouragement and development policies performed by the State.

\section{References}

ARRILLAGA, H. (1997): Una síntesis de la evolución de la oferta técnica de métodos evaluativos de proyectos de Inversión; en ARRILLAGA, H. (comp.); Evaluación de Proyectos de inversión. Hacia la construcción de nuevas perspectivas, Ediciones UNL, Santa Fe.

ARRILLAGA, H., Grand, L., Busso, G. (2009):Vulnerabilidad, riesgo y desastres. Sus relaciones de causalidad con la exclusión social en el territorio urbano santafecino en Herzer y Arrillaga(coord.) La construcción social del riesgo y el desastre en el aglomerado Santa Fe, Ediciones UNL, Santa Fe.

AZQUETA OYARZUN, D. (1994):Valoración económica de la calidad ambiental, Colombia, Ed. Mc. Graw Hill..

BACA URBINA, G. (1992): Evaluación de Proyectos 2da. Ed. Análisis yAdministración del Riesgo, Ed.Mc Graw-Hill,México.

BAUMOLW. (1972): On Taxation and the Control of externalities, AER.

BECK, U. (1999): La sociedad del riesgo. Hacia una nueva modernidad, Ed. Paidos, Barcelona.

(200I) Retorno a la Teoría de la Sociedad del Riesgo. Boletín de la A.G.E. $N^{\circ} 30$.

BERIAIN, J. (Comp): Giddens, A., Baumann, Z., Lhumann, N., Beck, U. (2007): Las consecuencias perversas de la modernidad. 2da Edición. Antrhopos Ed, Barcelona.

BUSTAMANTE DOMAS, J. (200I): Hacia la cuarta generación de Derechos Humanos: repensando la condición humana en la sociedad tecnológica. Revista Interamericana de Ciencia, Tecnología, Sociedad e Innovación. Nro. I. Ed. OEl.

CALDERÓN VÁZQUEZ, F. (2008): Una Perspectiva Social de la Innovación. Contribuciones a las Ciencias Sociales, julio. (www.eumed.net/rev/cccss/02/fjcv.htm)

CARDONA, O. (200I): La necesidad de representar de manera holística los conceptos de vulnerabilidad y riesgo. Una crítica y una revisión necesaria para la gestión". Centro de estudios sobre Desastres y Riesgos. Universidad de los Andes, Bogotá,. http://www. desenredando.org/public/articulos/2003/rmhcvr/rmhcvr_may-08-2003.pdf

CASTEL, R. (2004): La inseguridad social. ¿Qué es estar protegido? Buenos Aires, Ed. Manantial.

ISSN: 07 I8-2724. (http://www.jotmi.org) 
COHEN E. y Franco R. (1998): Evaluación de proyectos sociales; ILPES; Buenos Aires, Grupo Editor Latinoamericano. DOUGLAS, M. (1996): La aceptabilidad del riesgo según las ciencias sociales. Barcelona, Ed. Paidos Ibérica.

DUPUIT, J. (1969): Sobre la medición de la utilidad de las obras públicas, I884. (Traducción al inglés publicada en $\mathrm{K}$. Arrow y T. Scitovsky (eds); Reading in welfare economics; American Economic Association; Allen \& Unwin, Londres.

ESCORSA CASTELLS P., Valls Pasola, J. (2003): Tecnología e innovación en la empresa; Colección: Politext; Editorial: Universitat Politècnica de Catalunya y Organización de Estados Iberoamericanos para la Educación, la Ciencia y la Cultura (OEI).

GIDDENS,A. (2005): Un mundo desbocado: los efectos de la globalización en nuestras vidas. Taurus, Madrid.

HERZER, H., Caputo, M., Celis, A. (2004): Gestión de riesgos de desastre ENSO en América Latina. Propuesta de consolidación de una red regional de investigación comparativa, información y capacitación desde una perspectiva social. CENTRO, Estudios Sociales y Ambientales, Buenos Aires.

HOWALDT, J. y Schwarz M. (2010): Social Innovation: Concepts, research fields and international trenes; Sozialforschungsstelle Dortmund - ZWE der TU-Dortmund.

HEWITT, K. (1983): The idea of calamity in a technocratic age en Hewitt Interpretation of calamity. Allen \& Unwin Inc. New York.

INFANTE VILLARREAL, A. (1998): Evaluación Financiera de Proyectos de Inversión. Editorial Norma; Colombia.

LÓPEZ CEREZO,J.Y Luján López,J. (2000): Ciencia y política del riesgo. Alianza Editorial, Madrid.

LAVELL, A. (2004): Antecedentes, formación y contribución al desarrollo de los conceptos, estudios y la práctica en el tema de los riesgos y desastres en América Latina: 19802004. La RED.

MANSILLA, E. (1996): Notas para una reinterpretación de los desastres, en Desastres. Modelo para armar; Instituto de Investigaciones Económicas, UNAM, La RED.

Manual de Oslo (2005): Guía para la recogida e interpretación de información de datos sobre innovación. 3era Edición. OCDE y Eurostat. Comunidad Europea.

MARTINEZ ALLIER, J. ( 1998): Curso de economía ecológica; PNUMA, Oficina Regional para América Latina y el Caribe.
MARSHALL,A. (I890): Principles of economics:An introductory volumen. Canada.

MAX NEEF, M. Elizalde A.Y Hopenhayn M. (1993): Desarrollo a Escala Humana. Conceptos, aplicaciones y algunas reflexiones: Editorial Norma (En base a la edición de Development dialogue, número especial de 1986 , en español, editado por la Fundación Dag Hammars-kjóld, Uppsala, Suecia, traducciones del libro Human scale development, ed. The Apex Prexx, Nueva York, EE.UU); Uruguay.

MOKATE KAREN M. (1987): La evaluación socioeconómica de proyectos de inversión. El estado del arte; http://www. saber.ula.ve/bitstream//23456789/19346/2/articulo7.pdf Lectura: I2 Mayo 201 I.

MONTOYA SUAREZ, O. (2004): Schumpeter, innovación y determinismo tecnológico; Scientia et Technica Año X, Nro 25. UTP.

MULGAN G., Tucker S., Ali R. Y Sunders B. (2007): "Social innovation: What it is, Why it mutters and How can be accelerated", Oxford Sail School,Working paper, Oxford.

PÉREZ DE ARMIÑO, C. (1999): Vulnerabilidad y desastres. Causas estructurales y procesos de la crisis de África, en Cuadernos de trabajo $\mathrm{N}^{\circ} 24$, HEGOA, Universidad del País Vasco, Bilbao.

PIGOU,A. (1920): La economía del bienestar.

RODRÍGUEZ VARGAS, J. (2005): La nueva fase de desarrollo económico y s del capitalismo mundial.Tesis Doctoral; UNAM, México.

SÁNCHEZ DEL VALLE, R. (200I): Dimensión de género en la gestión Local de Riesgo. GTZ.

SAPAG CAHIN, N. (1998): Criterios de Evaluación de proyectos: Cómo medir la rentabilidad de las inversiones. Colombia, Serie Mc. Graw-Hill de Management.

SCHUMPETER, J. (1978): Teoría del desarrollo económico. Ed. Fondo de Cultura Económico. México.

SEPÚLVEDA PALACIOS, F. (2000): Las metodologías de evaluación social; http://www2. udec.cl/ fsepulve/pdf/6metsocial. pdf ; - Lectura: 26 Mayo 201 I

SOLANET, M., Rapetti, E., Cozzetti, A. (1984): Evaluación económica de proyectos de inversión. El Ateneo Editorial, Buenos Aires.

ISSN: 07 I8-2724. (http://www.jotmi.org)

Journal of Technology Management \& Innovation (c) Universidad Alberto Hurtado, Facultad de Economía y Negocios. 
WEBER, Max (1996): La Ética Protestante y el Espíritu del Capitalismo. Fondo de Cultura Económica, México.

SOLOW R.: A. (1956): Contribution to the Theory of Economic Growth. The Quarterly Journal of Economics, Vol. 70, $N^{\circ}$ I, pp 65-94, 